\title{
Lung Abscess as a Complication of Pneumonia in 19-month Old Child
}

\author{
Dejana D. Bajić́ ${ }^{1}$ Nemanja B. Todorović2 , Nikola M. Eić1, \\ Mladena N. Lalić-Popović ${ }^{2}$, Boris Ž. Milijašević ${ }^{3}$
}

${ }^{1}$ Institute for Child and Youth Health Care of Vojvodina, Hajduk Veljkova 10, 21000 Novi Sad, Serbia

${ }^{2}$ Department of Pharmacy, Faculty of Medicine, University of Novi Sad, Hajduk Veljkova 3, 21000 Novi Sad, Serbia

${ }^{3}$ Department of Pharmacology, Toxicology and Clinical Pharmacology, Faculty of Medicine, University of Novi Sad, Hajduk Veljkova 3, 21000 Novi Sad, Serbia

\section{SUMMARY}

Introduction: Community-acquired pneumonia is one of the most common diseases in infancy but most of these diseases have relatively simple course. We are presenting a case of child who developed lung abscess as a complication of pneumonia.

Case Report: The goal of our case report is to point out that lung abscess is a relatively rare entity whose development is not always typical, sudden and acute, but also hidden, inconspicuous and perfidious. Although clinical picture and laboratory findings indicated that the pneumonia was cured, a single control CT scan showed that there was inflammation (hotspot) in the organism.

Discussion: Lung abscess is a rare state which is developed as a complication only at $1 \%$ of pneumonias. Complications are rare and depend on the previous immunological status of the child and the presence of comorbidity. The duration of antibiotic therapy depends on the clinical and radiographic response of the patient. The chosen antibiotics have to cover a wide specter of Gram-positive and Gram-negative bacteria.

Conclusions: The key role in making a diagnosis played radiological methods which were crucial in monitoring the evolution of the change itself, from its creation to regression. The triple antibiotic therapy with meropenem, vancomycin and metronidazole enabled an (excellent) recovery outcome.

Keywords: pulmonary abscess, pediatrics, drug therapy, antibiotics, computed tomography

\section{INTRODUCTION}

Although community-acquired pneumonia (CAP) mortality in well-developed countries decreased significantly in the last decades [1], it remains one of the leading causes of morbidity in childhood. At the same time, an increasing incidence of local CAP complications has been reported [2]. These include parap- neumonic effusion (PPE)/pleural empyema $(\mathrm{PE})$, necrotizing pneumonia (NP), and lung abscess [3]. In some patients, the signs and symptoms associated with local complication may be the initial manifestations of CAP [4]. However, in the vast majority of children, these complications develop later in the course 
of the disease [5]. The increasing incidence of local complications was observed not only in untreated or inadequately treated children but also in patients treated in accordance with current guidelines [4]. Lung abscess is a relatively rare CAP complication in immunocompetent children with incidence rates below one percent (1\%) of all cases [6]. We are presenting a case of child who developed lung abscess as a complication of pneumonia.

\section{CASE REPORT}

This case report refers to second child from second regularly controlled pregnancy ended within the term with an elective caesarean section (C-section), somatometric parameters at the level of the referent values for that age. The child has been regularly vaccinated (with an exception of the MMR vaccine) and without allergic reactions to food and medicaments. The child has had two bronchial obstructions treated with bronchodilator - short acting $\beta 2$ receptor agonist fenoterol and anticholinergic ipratropium bromide (Berodual $\mathrm{N}^{\circledR}$ solution for inhalation $0.5 \mathrm{mg} / \mathrm{ml}+0.25 \mathrm{mg} / \mathrm{ml}$ Boehringer Ingelheim Pharma $\mathrm{GmbH} \& \mathrm{Co}$. $\mathrm{KG}$, Germany) at a dose of $0.3 \mathrm{ml}$ every eight hours and corticosteroid budesonide (Pulmicort Respules ${ }^{\oplus}, 500 \mu \mathrm{g} /$ dose, Astra Zeneca, Sweden) inhalations at a dose of $1 \mathrm{ml}$ - twice a day along with the antibiotic so far.

A 19-month old boy was admitted to our hospital with the symptoms of high (elevated) body temperature, fatigue, non-productive cough, severe dyspnea and increased nasal congestion. The first symptoms had appeared four days before admission in the form of fever (up to 40 degrees Celsius) and irritating dry cough. He was examined by a pediatrician in healthcare center and the initial treatment included two antibiotics: clarithromycin (Klacid $^{\otimes} 125 \mathrm{mg} / 5 \mathrm{ml}$, AbbVie S.R. L., Italy) at a dose of $3 \mathrm{ml}$ twice a day and cefpodoxime (Tridox ${ }^{\circ}$ $40 \mathrm{mg} / 5 \mathrm{ml}$, Alkaloid AD Skopje, North Macedonia) at a dose of $5 \mathrm{ml}$ every twelve hours in the form of a peroral suspension. Additionally, the inhalation of fixed-dose combination of two bronchodilators short acting $\beta 2$ receptor agonist fenoterol and anticholinergic ipratropium bromide (Berodual $\mathrm{N}^{\circledast}(0.05+0.21) \mathrm{mg} /$ dose, Boehringer Ingelheim Pharma GmbH \& Co. KG, Germany) at a dose of $0.3 \mathrm{ml}$ every six hours were applied, as well as a corticosteroid budesonide (Pulmicort Turbuhaler ${ }^{\circledR}, 500 \mu \mathrm{g} /$ dose, AstraZeneca, Sweden) at a dose of $1 \mathrm{ml}$ twice a day. Since the child's health condition was getting worse, he was transferred to the Institute for further diagnostic and treatment.

On admission he was conscious and alert, pale, subfebrile with rectal temperature of 37.5 degrees Celsius, tachypneic with the respiratory rate (RR) of forty breaths per minute, oxygen saturation of $96 \%$ on room air, heart rate of 140 beats per minute and the normal body weight of $10.85 \mathrm{~kg}$ ( $75^{\text {th }}$ percentile). On examination beside stuffy nose and hyperemic pharynx, lung auscultation revealed diminished breath sounds with early inspiratory crackles. All other physical findings were normal. The initial analysis showed significantly raised level of inflammatory marker CRP $249 \mathrm{mg} / \mathrm{L}$, whereas complete blood count was within the reference range. First chest Xray performed on admission showed denser condensations of the both sides of the lung parenchyma - paracardially in the upper and middle pulmonary field and hilobasal on the right side, as well as in the middle and lower pulmonary field on the left side (see picture no. 1). After admission, a double antibiotic

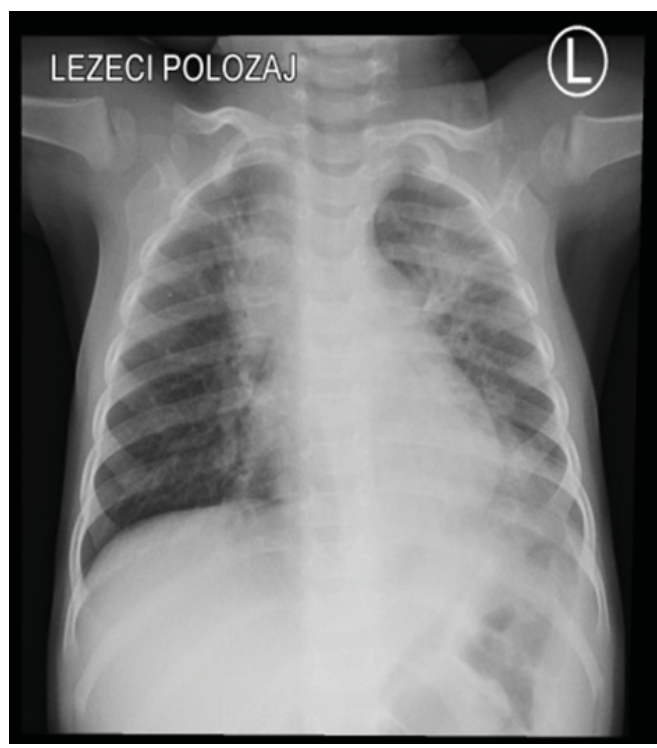

Picture 1. Pneumonia intravenous therapy with cephalosporin of the third generation of ceftazidime (Forcas, GlaxoSmithKline Manufacturing s.p.a., Italy) at a dose of $500 \mathrm{mg}$ was included every eight hours, together with clindamycin (Clindamy$\mathrm{cin}^{\circ}$, HemofarmAD, Serbia) at a dose of 100 mg every six hours. The inhalations with Berodual $^{\bullet}$ and Pulmicort ${ }^{\circledR}$ continued with the gradual prolongation of the intervals between the inhalations. In spite of the applied thera- 
Picture 2. Lung abscess

Picture 3. CT scan of abscess

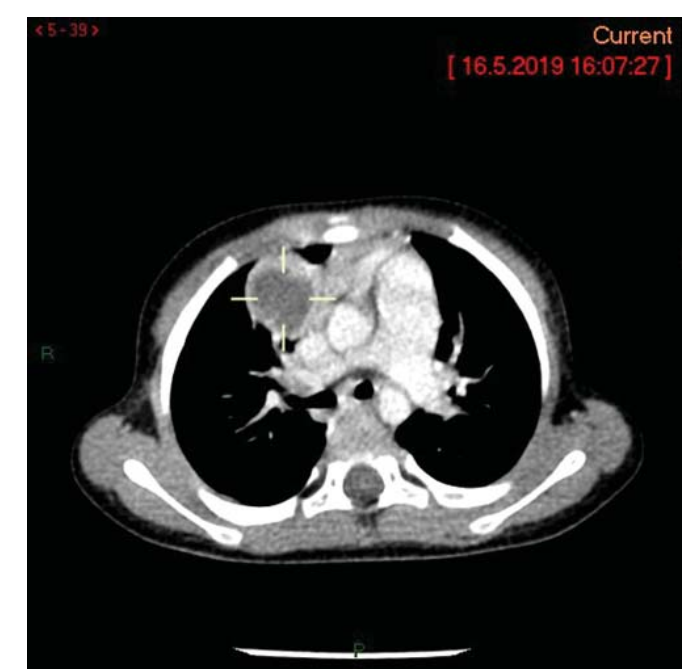

Picture 4. Sagital plane of chest and abscess

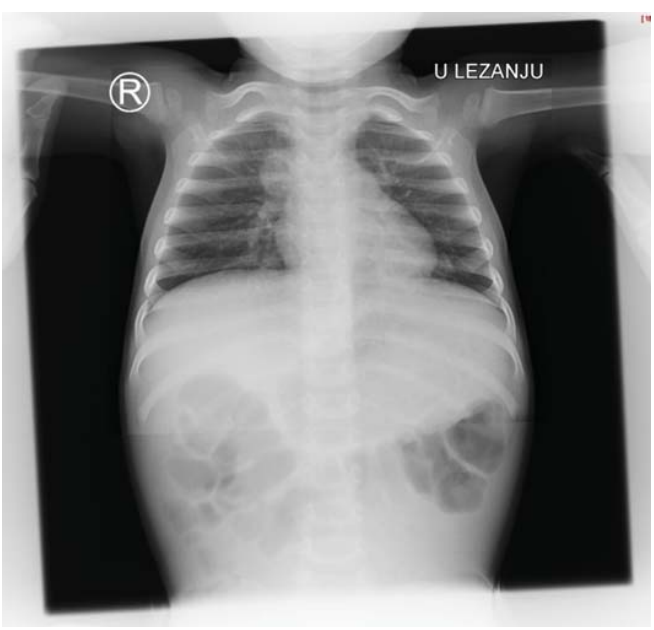

py fever lasted for ten days followed by night sweats. On the $14^{\text {th }}$ day of hospitalization, when the patient was clinically stable the intravenous antibiotic therapy was switched to oral - cefixime suspension (Pancef ${ }^{\infty}$, Alkaloid AD Skopje, North Macedonia) at a dose of $4 \mathrm{ml}$ once per day. Further clinical course showed the improvement of the finding at ausculta-

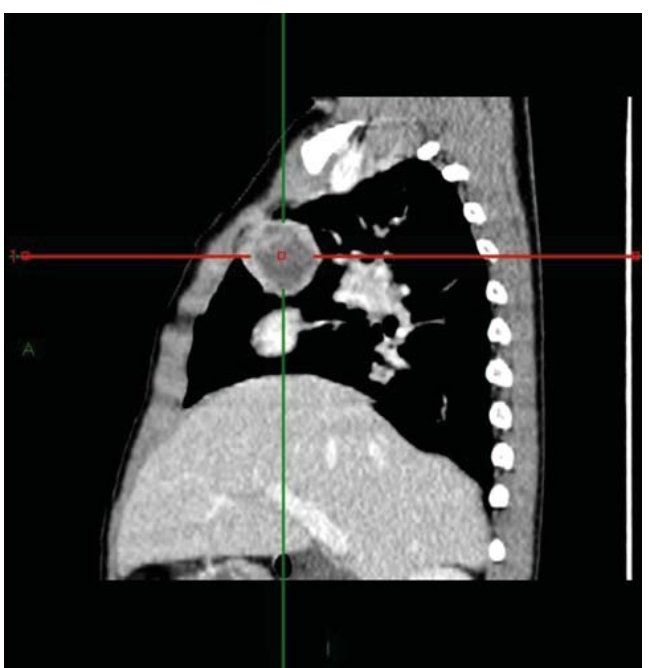

tion of the lungs, which was normal. The chest $\mathrm{X}$ - ray on the $20^{\text {th }}$ day of treatment revealed a newly discovered, clearly outlined half-spherical shadow of about $21 \mathrm{~mm}$ on the right side of in the upper mediastinum next to the heart shadow along with the small stain condensations of the lung parenchyma (picture no. 2). The clinical course indicated recovery (the child was not febrile any more, the parameters of infection decreased, auscultation findings were without pathological sound phenomena), but meanwhile an inflammatory change discovered by chance was located. The ultrasound of the lungs was done first, and because the findings were not clear, the X-ray scans of the lungs and the heart were done additionally. A pulmonologist was consulted and because of the evaluation of the suspected change, a CT scan of the lungs with contrast was carried out as well.

In the upper lung lobus paracardially, on the right and next to the pericardium, a round, relatively clearly outlined hypodense lesion with the dimensions of $26 \times 25 \times 25$ $\mathrm{mm}$ (AP x LL x CC) was noticed (picture no. 3). Following administration of the contrast agent, it showed primarily at the edge but partly at the center as well, and according to its CT characteristics indicated abscess (picture no. 4). The smaller zones of lung parenchyma condensation on the right with the distinctive hypodense zones were recoreded. A thorough diagnostic evaluation of the lesion etiology included bronchoscopy and the examination of broncholates (bacteriological, cytopathological, mycological micro bacteria testing), gastric lavages and the diagnostic testing for tuberculosis (QuantiFERON test and PPD probe). On $22^{\text {nd }}$ day of hospitalization a triple intravenous antibiotic therapy with vancomycin, meropenem and metronidazole over a period of at least three weeks and in accordance with the handbook for treating abscess was involved. This therapy covered Gram positive and Gram-negative aerobes and anaerobes. Prior to the enhanced antibiotic therapy, hemoculture and blood tested for viruses (the most common cause of pneumonia) had been taken indicating slightly higher IgM of antibodies of Mycoplasma pneumonia and when the results arrived clarithromycin suspension was included into the therapy. Because the assessment of the immunology status was necessary, an immunologist was consulted and the immunology examination was carried out, 
together with immunophenotyping of lymphocytes and determining the subclass of IgG antibodies. The results showed that the absolute number of B lymphocytes was decreased to the referent range according to age, while the absolute number of T lymphocytes and NK cells as the ratio of CD4 : CD8 were normal. ELISA test for Toxoplasma gondii (IgM and IgG negative) was carried out differentially as well as the test of indirect hemagglutination for echinococcosis which was also negative. During the hospitalization, US of the lungs and CT of the chest were performed a number of times, justifying the applied therapy, with the gradual regression of the abscess. Having been implemented for three weeks, the applied therapy was suspended and replaced with ampicillin sulbactam (Ampisulcillin $1000 \mathrm{mg}+$ $500 \mathrm{mg}$, ZDRAVLJE AD Leskovac, Serbia) at a dose of $500 \mathrm{mg}$ every eight hours parenterally and ciprofloxacin (Marocen $100 \mathrm{mg} / 10$ $\mathrm{ml}$, Hemofarm AD, Serbia) at a dose of $100 \mathrm{mg}$ three times a day during the period of seven days.

All intravenous therapy was suspended during the last week of hospitalization and the patient was switched to amoxicillin plus clavulanic acid suspension (Panklav forte 250 $\mathrm{mg}+62.5 \mathrm{mg} / 5 \mathrm{ml} \mathrm{Hemofarm} \mathrm{AD,} \mathrm{Serbia)} \mathrm{at}$ a dose of $1.6 \mathrm{ml}$ three times a day. The applied therapy resulted with the improved health condition of the patient and findings on the lungs, while the characteristic of abscess cleared up almost completely (pictures no. 5 and 6.). The patient was regularly monitored by the pulmonologist and immunologist, while US of the lungs was occasionally applied and it was normal.

\section{DISCUSSION}

Lung abscess is a tick-walled cavity in the pulmonary parenchyma that contains purulent material and is initiated or complicated by infectious organisms [7]. Lung abscess is classified as primary or secondary depending on underlying conditions. Primary lung abscess occurs in the absence of a specific lung disease, while secondary lung abscess occurs in the presence of predisposing structural or functional lung diseases including congenital lung disorders, ciliary dyskinesia and cystic fibrosis, systemic diseases such as neuro-developmental abnormalities and congenital immunodeficiencies that may lead to aspiration

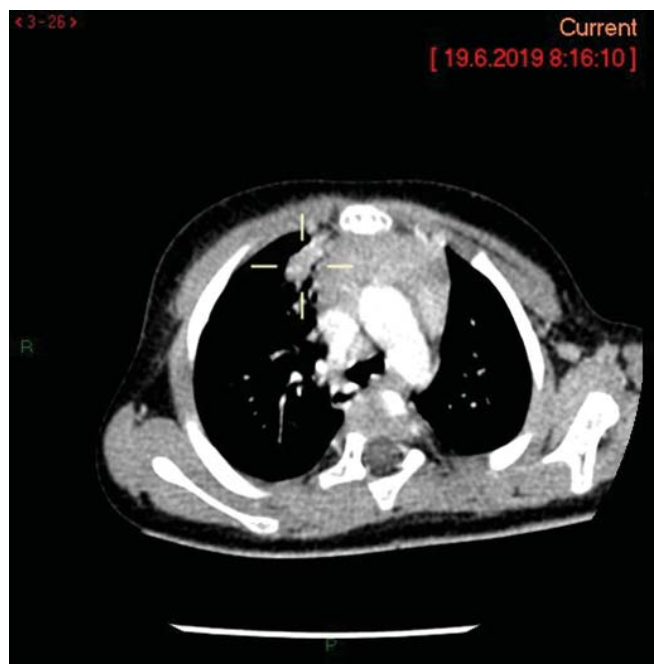

Picture 5. CT scan after therapy

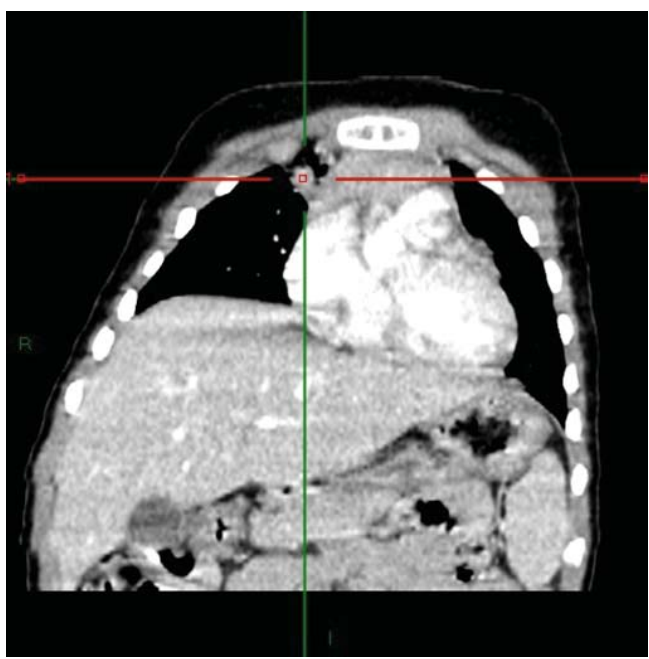

Picture 6. Regression of abscess

or infection [8].

The introduction of microbials into clinical practice has improved the prognosis of lung abscess, but the literature from 1969 to 2005 reported mortality rates ranging from $2.0 \%-38.2 \%$ [9]. Pediatric lung abscess can occur at any age and morbidity is lower than that in adults [7]. The clinical signs and therapy of lung abscess were described for the first time by Hippocrates. In pre-antibiotic era, one third of patients with lung abscess would die, the other third of patients would fully recover, and the rest would survive with sequels such as chronic lung abscess, pleural empyema or bronchiectasis [10]. In pre-antibiotic era, lung abscess was caused by one type of bacteria, and today almost in all cases is caused bypolymicrobial flora [11]. From anaerobic bacteria in lung abscess predominant bacteria isolates are gram-negative Bacteroidesfragilis, Fusobacteriumcapsulatum and Necrophorum, grampositive anaerobic Peptostreptococcus and Microaerophilic streptococci. From aerobic 
bacteria predominant bacteria isolates in lung abscess are Staphylococcus aureus (including methicillin resistant Staphylococcus aureus MRSA). Streptococcus pyogenes and pneumonia, Klebsiella pneumonia, Pseudomonas aeruginosa, Hemophilus influenza (type B), Acinetobacterspp, Escherichia coli, and Legionella [12].

The duration of antibiotic therapy depends on the clinical and radiographic response of the patient [13]. According to the guidelines, intravenous therapy should be applied for at least three weeks, and then it should be switched to the oral form in such a way that the complete duration of the treatment is not beyond six weeks [14]. The chosen antibiotics have to cover a wide specter of Gram-positive and Gram-negative bacteria [15]. The differential diagnosis is particularly significant because of a non-specific clinical picture with relatively common signs and symptoms of the disease such as non-productive cough, fever and night sweat. The additional diagnostic should confirm or reject the following entities: excavating bronchial carcinoma (squamouscell or microcellular), excavating tuberculosis, localized pleural empyema, infected emphysematous bullae, cavitary pneumoconiosis, hiatus hernia, pulmonary hematoma, hydatid cyst or lungs, cavitary infarcts of lungs, Wegener's granulomatosis [13].

Diagnostic bronchoscopy is a part of diagnostic protocol for taking the material for microbiological examination and to confirm intrabronchial cause of abscess - tumor or foreign body [16]. Bronchoscopy should be an integral part of the algorithm for diagnostic and therapy of lung abscess [13]. The examination of bronchial aspirate culture, broncholavage and gastric lavage showed that the microbiological cultures were without bacterial increase. The cytopathological analysis showed the presence of mucus, rare cylindrical cells and lipid laden macrophages in broncholavage. While making a diagnosis, besides the clinical picture which is the starting point, imaging methods and the response of the organism to the applied therapy are also crucial. If the lung diseases are suspected, the first step is a chest X-ray, which is still in practice as the most common diagnostic method although it belongs to ionizing radiation. Computerized tomography is more advanced in the diagnostic algorithm and CT scans will not be used for detecting every case of pneumonia. This meth- od is a "backup" method in particular cases that are not clear and where better magnifying power is necessary to enable a clear detection of the changes.

In the cases where a concrete microbiological flora has not been isolated, which is considered as a primary causative agent for the development of abscess, empiric therapy has to be conducted in such a way to cover the most dangerous and/or the most frequent causative agents. In our case were chosen backup antibiotics of which some can go through hematoencephalic barrier, while others cover Gram-positive and Gram-negative aerobic and anaerobic. Meropenem, vancomycin and metronidazole were the proper choice because their targeted use in the period of three weeks resulted with the regression of abscess almost completely. According to the recommendations of the guidelines, antibiotic therapy should last until the visible clinical and radiological signs of the abscess regression appear [17]. The child has been controlled on a regular basis since the treatment by the pulmonologist and immunologist. The child does not have any difficulties and his body mass index has increased.

\section{CONCLUSION}

Lung abscess is a rare complication of pneumonia in infancy, and its atypical clinical picture is a proof that in spite of the standard antibiotic therapy (treatment), the response of the organism is always individual. Radiological diagnostic was used to control and monitor the course of abscess treatment, from its recognition to regression. The combination of antibiotics that led to recovery included meropenem, vancomycin and metronidazole.

\section{CONFLICTS OF INTEREST}

All authors declare no conflict of interest.

\section{INFORMED CONSENT OF PARENT}

The mother of this patient gave us signed permission to write a case report.

\section{REFERENCES}

1. Rudan I, Boschi-Pinto C, Biloglav Z, Mulholland $\mathrm{K}$, Campbell H. Epidemiology and etiology of childhood pneumonia. Bulletin of the world health organization. 2008;86:408-16B. 
2. Fletcher MA, Schmitt HJ, Syrochkina M, Sylvester G. Pneumococcal empyema and complicated pneumonias: global trends in incidence, prevalence, and serotype epidemiology. European journal of clinical microbiology \& infectious diseases. 2014;33(6):879910.

3. Prayle A, Atkinson M, Smyth A. Pneumonia in the developed world. Paediatric respiratory reviews. 2011;12(1):60-9.

4. Lahti E, Peltola V, Virkki R, Alanen M, Ruuskanen O. Development of parapneumonic empyema in children. ActaPaediatrica. 2007;96(11):1686-92.

5. Krenke K, Krawiec M, Kraj G, Peradzynska J, Krauze A, Kulus M. Risk factors for local complications in children with community-acquired pneumonia. The clinical respiratory journal. 2018;12(1):253-61

6. Pabary R, Balfour-Lynn IM. Complicated pneumonia in children. Breathe 2013;9:210-22.

7. Patradoon-Ho P, Fitzgerald DA. Lung abscess in children. Paediatric respiratory reviews. 2007;8(1):77-84.

8. Choi MS, Chun JH, Lee KS, RhaYH, Choi SH. Clinical characteristics of lung abscess in children: 15 year experience at two university hospitals. Korean journal of pediatrics. 2015;58(12):478.

9. Takayanagi N, Kagiyama N, Ishiguro T, Tokunaga D, Sugita Y. Etiology and outcome of communityacquired lung abscess. Respiration. 2010;80(2):98105.

10. Bartlett JG. The role of anaerobic bacteria in lung abscess. Clin Infect Dis 2005;40:923-5.

11. Yazbeck MF, Dahdel M, Kalra A, Browne AS, Pratter MR. Lung abscess: update on microbiology and management. American journal of therapeutics. 2014;21(3):217-21.

12. Wang JL, Chen KY, Fang CT, Hsueh PR, Yang PC, Chang SC. Changing bacteriology of adult community-acquired lung abscess in Taiwan: Klebsiellapneumoniae versus anaerobes. Clinical infectious diseases. 2005 Apr 1;40(7):915-22.

13. Kuhajda I, Zarogoulidis K, Tsirgogianni K, Tsavlis $D$, Kioumis I, Kosmidis C, et al. Lung abscess-etiology, diagnostic and treatment options. Annals of translational medicine. 2015;3(13):183-92.

14. Levison ME, Mangura CT, Lorber B, Abrutyn E, Pesanti EL, Levy RS, Macgregor RR, Sshwartz AR. Clindamycin compared with penicillin for the treatment of anaerobic lung abscess. Annals of internal medicine. 1983;98(4):466-71.

15. Allewelt $M$, Schüler $P$, Bölcskei $P L$, Mauch H, Lode H. Ampicillin+ sulbactam vs. clindamycin \pm cephalosporin for the treatment of aspiration pneumonia and primary lung abscess. Clinical microbiology and infection. 2004;10(2):163-70.
16. Nagashima $O$, Sasaki $S$, Nanba $Y$, Katsura $Y$, Takekawa H, Kuriyama S, et al. Analysis of predominant bacterial species and clinical backgrounds in lung abscess patients. Nihon Kokyuki Gakkai zasshi. 2011;49(9):623-8.

17. Mustafa M, Iftikhar HM, MuniandyRK, Hamid SA, Sien MM, Ootha N. Lung abscess: Diagnosis, Treatment and Mortality. International Journal of Pharmaceutical Science Invention. 2015;4(2):37-41. 


\title{
Apsces pluća kao komplikacija pneumonije deteta uzrasta 19 meseci
}

\author{
Dejana D. Bajić ${ }^{1}$, Nemanja B. Todorović 2 , Nikola M. Eić ${ }^{1}$, Mladena N. Lalić-Popović ${ }^{2}$ \\ Boris Ž. Milijašević ${ }^{3}$ \\ ${ }^{1}$ Institutut za zdravstvenu zaštitu dece i omladine Vojvodine, Novi Sad, Srbija \\ ${ }^{2}$ Katedra za farmaciju, Medicinski fakultet, Univerzitet u Novom Sadu, Novi Sad, Srbija \\ ${ }^{3}$ Katedra za farmakologiju, toksikologiju i kliničku farmakologiju, Medicinski fakultet, Univerzitet u \\ Novom Sadu, Novi Sad, Srbija
}

\section{KRATAK SADRŽAJ}

Uvod: Pneumonije su jedne od najčešćih bolesti u dečijem uzrastu, ali većina njih su relativno jednostavnog toka. Prikazaćemo slučaj deteta koje je razvilo apsces pluća kao komplikaciju pneumonije.

Prikaz slučaja: Cilj našeg prikaza slučaja je bio da se ukaže na apsces pluća kao relativno redak entitet, čiji razvoj ne mora uvek biti tipičan, iznenadan i burnog toka, već i pritajen, neupadljiv i podmukao. lako su tokom lečenja klinička slika i laboratorijski nalazi išli u prilog izlečenja pneumonije, jedan kontrolni snimak pluća ukazao je da se u organizmu u međuvremenu stvorilo žarište.

Diskusija: Apsces pluća je retko stanje koje se razvije kao komplikacija u svega $1 \%$ pneumonija. Komplikacije su retke i zavise od prethodnog imunološkog statusa deteta i prisustva komorbideta. Trajanje terapije zavisi od kliničkog i radiološkog odgovora. Izabrani lekovi trebali bi da pokriju širok spektar Gram pozitivnih i Gram negativnih bakterija.

Zaključak: Ključnu ulogu u postavljanju dijagnoze imale su radiološke metode, a dale su i konačnu reč u praćenju evolucije same promene od njenog nastanka do regresije. Trojna antibiotska terapija meropenem, vankomicin i metronidazol dali su odličan rezultat.

Ključne reči: pulmonarni absces, pedijatrija, terapija lekovima, antibiotici, kompjuterizovana tomografija 